\title{
Mobile-Assisted Pronunciation Training: The Google Play Pronunciation and Phonetics Application
}

Universitas Kutai Kartanegara Tenggarong, Indonesia

Email Correspondence: fitriameisarah@ unikarta.ac.id

\section{Background:}

Abstract

Several obstacles to pronunciation have been proposed and urged students to practice pronunciation deliberately. Regardless of these problematic, mobile applications can be a great assistant in pronunciation training. However, considering that Google Play is the most prominent android app store with 227,970 instructional devices, it is challenging to find and select pronunciation and phonetics applications. Students should be conscious of their needs by recognizing the proper mobile application for pronunciation learning. This study explores the pronunciation applications utilized by students for pronunciation learning in and out of the classroom.

\section{Methodology:}

This study administered the data with paper reports and interviews accompanying students. This study involved 41 students who were taking a pronunciation and phonetics course at the University of Kutai Kartanegara Tenggarong.

Findings:

Nine such applications, as reviewed in this study, are divided into two categories: English pronunciation special purpose (EPSP) application and English dictionary assisted pronunciation (EDAP) application. Noteworthy findings were not all of the applications fulfill the content and design approaches such the suprasegmental features, audio playback, and video camera recorder.

\section{Conclusion:}

This study endeavors to have a critical look at four applications recommended after concerning the term of Mobile Assisted Pronunciation Training (MAPT). They are AV Phonetic, English Phonetic Pronunciation, Listening Practice, English Pronunciation developed by Kepham, and U-Dictionary to assist pronunciation learning in and out of the classroom.

Keywords: Pronunciation; phonetics; mobile application; MAPT.

\section{DOI $\quad: \quad$ http//dx.doi.org/10.24903/sj.v5i2.487}

\begin{tabular}{|l|l|l|}
\hline Received & $:$ & July 2020 \\
\hline Accepted & $:$ & August 2020 \\
\hline Published & $:$ & October 2020 \\
\hline Copyright Notice & $:$ & $\begin{array}{l}\text { Authors retain copyright and grant the journal right of first publication with the } \\
\text { work simultaneously licensed under a Creative Commons Attribution 4.0 }\end{array}$ \\
International License that allows others to share the work with an acknowledgment of
\end{tabular}

Copyright Notice 


\section{INTRODUCTION}

Pronunciation is one of the language skills stands on two various viewpoints: segmental and suprasegmental (Darcy, 2018; Deterding, 2015; Foote et al., 2016; Mirza, 2015; Munro \& Derwing, 2015; Saito \& Saito, 2017; Thomson \& Derwing, 2015; Zielinski, 2015). The first viewpoint is related to individual sound as the minimal unit of sound determined in phonetic terms and phonetics forms of phonemes in particular environments within syllables and words. In comparison, the second viewpoint is linked to general articulatory features of stretches of speech close to syllable structure, linked speech, stress, rhythm, and intonation. Maintaining a balance both segmental and suprasegmental is regarded as best practice (Burri, 2016; Crowther et al., 2015; Darcy, 2018; Ma'u et al., 2019). However, suprasegmental tend to be taught less frequently than segmental because they are challenging to teach and learn (Burri, 2016; Buss, 2016; Couper, 2017; Foote et al., 2016). According to them, common difficulties related to suprasegmentals include utterance stress, intonation, and rhythm. Nevertheless, some scholars (Cutler, 2015; Levis \& Wichmann, 2015; Low, 2015; Saito \& Saito, 2017) have been explored the ever-important yet most neglected of these parts of suprasegmental problems. In contrast, Darcy (2018) has been written that if the segments are unintelligible, the suprasegmental features would be useless. Alike suprasegmental, teaching segmental manner also facing difficulties. Current studies found that vowel sound (lax and tense), dental fricative consonants, minimal pair, and connected speech are the most common segmental errors (Burri, 2016; Buss, 2016; Couper, 2017; Levis \& Alameen, 2015; O'Neal, 2015). Therefore, several strategies for learning pronunciation, namely cognitive strategies and social strategies, might be used (Mirza, 2015; Szyszka, 2015; Véliz-Campos, 2018). These strategies consist of phonetics transcription, repetition, imitation, minimal pair drills, reading aloud, pronunciation rule, peer correction, using English media, and soon.

The core of pronunciation is to achieve the goal of ensuring intelligibility and comprehensibility instead of native-like Pronunciation (Buss, 2016; Darcy, 2018; Lim, 2016; Munro \& Derwing, 2015; O'Neal, 2015; Sun, 2017; Thomson \& Derwing, 2015; Zielinski, 2015). In a nutshell, intelligibility defines as recognition of word and utterance, while comprehensibility refers to the meaning of an utterance. Many academics have investigated the intelligibility of different varieties of English (Sun, 2017). It means that intelligible language does not impede successful communication 'with Pronunciation in English as an international language (EIL). This set of characteristics is the Lingua Franca Core (LFC), in which the teacher can teach intelligible English as a Lingua Franca (ELF) (Lim, 2016; VélizCampos, 2018; Walker \& Zoghbor, 2015; Zoghbor, 2018). In comparison to the International 
Phonetic Alphabet (IPA) chart as the complete inventory of all known linguistic sounds to effective teaching pronunciation (Burri, 2016; Murphy \& Baker, 2015), the English varieties' pronunciation underlines the continuity of the word. Various cultures are intertwined, and in separate areas of the English speaking world, each has its own natural climate IPA chart is better known, especially the various vowel symbols that are not always in English (M. Reed \& Levis, 2015).

As the following issues based on the studies by Jing (2017), Xiao \& Luo (2015), and Zielinski (2015), the main obstacles in teaching and learning pronunciation were severely incompetent lecturers, limited teaching hours, and lack of prompt and meaningful individualized input. Limitation of teaching is caused by pronunciation as not a target aspect of the curriculum (Mahdi \& Al Khateeb, 2019). The English Education Department at the University of Kutai Kartanegara Tenggarong also faces these problems, which formatted pronunciation and phonetics course is taught only in one semester with the total amount of face-to-face learning around 22.5 hours. Regarding the last issues, enormous studies gain the importance of corrective feedback (CF), significantly recast to help students recognize that their pronunciation is an error, so they need to know precisely where it is, and then how to fix it (Baker \& Burri, 2016; Buss, 2016; Couper, 2019; Darcy, 2018; Gooch et al., 2016; Lim, 2016). However, CF is hardly for suprasegmental errors because they are recognized as such by native listeners but are misunderstood as behaviors that the speaker does not intend (Wichmann, 2015).

Despite the problematic complexity of teaching and learning pronunciation, mobile technology is reported can significantly enhance students' Pronunciation (Arashnia \& Shahrokhi, 2016; Fouz-González, 2015; Ghounane, 2019; Jing, 2017; Kaiser, 2018; Mompean \& Fouz-González, 2016; Walesiak, 2017). Using mobile application allows the student to activate the speech system by listening to pronunciation inputs, process to produce outputs, and a significant volume of intelligible feedback (Haggag, 2018; Hincks, 2015; Kaiser, 2018; Martins et al., 2016; Thomson \& Derwing, 2015; Walesiak, 2017). It becomes a rising awareness since the concept of Mobile-Assisted Pronunciation Training (MAPT) is coined by Kaiser (2018). The MAPT contains four principal features: (1) more specific resources for each student's needs; (2) unlimited for self-adjusted learning; (3) decreased fear due to secrecy; and (4) feedback on oral results in real-time. Besides, MAPT not just stress on user interface friendly, license, application developer, and file size, but also it embeds with several features such as audio, recorder (and playback), and video (or external video), feedback, video camera, and physical interaction such as touch screen, keyboard (qwerty and 
IPA), and accelerometer. The MAPT features summaries should be emphasized to the following phases in the learning process: input, output, and feedback. Another vital suggestion is that MAPT pays attention to the reorientation concerning the point-focus of segmental exercises, becoming more realistic practices centered on the suprasegmental features of expression and giving positive guidance to the student.

Studies were done by Kaiser (2018) and Walesiak (2017) investigated 15 applicationoriented-pronunciation on the Google Play and 30 pronunciation applications on the Apple App Store. They found that most pronunciation and phonetics applications focus on a defined range of segmental features, such as IPA symbols and transcription, individual words, minimal pairs, and focus on detailed instruction. Some pronunciation applications also included visual feedback to watch a video of lips pronouncing then comparing students' pronunciation to that of the model by activating the front-facing camera, nor allows them to hear each vowel sound and then shows an oval-shaped of lip pronouncing by looking at the dot shakes on the smartphone screen. However, there are little pronunciation applications that provide feedback in listening and repeating the modeled words. Besides, another important finding ought to need attention where only a few applications can be referred to in-class as a source of suprasegmental features: word-stress, linking, rhythm, intonation, and accentedness.

Much of MAPT researches has relied on the researchers' own initiating to tracing on pronunciation applications location both in Google Play and Apple Store. Abduh (2019) notes that students require determining and selecting specific applications based on their needs. Therefore, this recent study attends applications following students' experiences for assisting their pronunciation as part of self-directed learning. Further, the consideration to choose Google Play because it is the leader of the Android operating system in Indonesia and that has counted $227.970(8.94 \%)$ applications for education whereas over 30,000 applications through the English study categories subsist around 2,384 applications (Byrne \& Diem, 2014; Kemp, 2020; Moreno \& Vermeulen, 2015; Statista, 2019, 2020) with 712 specific applications related to pronunciation and phonetics (author tracking).

According to the Higher Education curriculum of Revolution Industri 4.0, disruptive learning technology, established by the Indonesian Minister for Education, will be another approach while developing the educational and learning reform in universities and colleges. Therefore, this study's result is essential to know about pronunciation and phonetics application that might be intended for efficiency and interactive in pronunciation training both in and out of the classroom to create agile learners forward 21st-century skills. Besides, 
since the mobile application is relatively rapid growth, and attempts must be made to become aware of it to proper the need for pronunciation and phonetics teaching and learning.

\section{METHODOLOGY}

Data were obtained from students studying pronunciation and phonetics at the Department of English Education at the University of Kutai Kartanegara Tenggarong, Indonesia. They were freshmen with a total amount of students were 41 students, eight males and 33 females (mean age $=17.2 ; \mathrm{SD}=3.2$ ).

In the empirical report administered at the beginning of the study, participants reported having the mobile device(s) with an Android operating system and owning-time around 2 to 3 years. Conversely, they have not installed pronunciation and phonetics applications before the enrolled study of the course. Therefore, at the initial, of course, specifically at the second meeting, the researcher asked them to install two applications on the Google Play, namely AV Phonetic and Sound Right, to assisted their phonetics learning. The researcher also suggested they deliberately download and install another pronunciation and phonetics application based on their need. In the last meeting of the course, the researcher collected their paper reports about the kind of pronunciation and phonetics application, which complementary their learning during one semester and done interviews about their rigid views about the application.

\section{FINDINGS}

According to data from the paper report, there were fifteen applications for pronunciation practice. Considering the purpose of this study was to explore a specialized pronunciation and phonetics-based application, the researcher then excluded six of them at the initial data analysis. Therefore, this study showed nine pronunciation-based applications. To make it easier, then all of the applications are classified into two classifications: English Pronunciation Special Purpose (EPSP) application and English dictionary assisted pronunciation (EDAP) application. EPSP application included six applications: AV Phonetic, English Phonetic Pronunciation, Listening Practice, Sound Right, English Pronunciation by BkiT Software, Learn Pronunciation, and English Pronunciation by Kepham. While, EDAP application consisted of three applications, specifically Google Translate, U-Dictionary, and Kamusku Inggris Indonesia.

Figure 1 attested to expose nine application assisted pronunciations and phonetics learning that ranked according to reported frequency of most installed (bottom-up). Noteworthy was, first of all, the low rankings of EPSP application in terms of interest of use 
were lower rather than EDAP application. It illustrated that either more the specific forms or the applications with a different primary focus have the benefit of supplementing pronunciation and phonetics learning. It was not a little bit surprising because the EDAP application has multiple advantages for students. It was not just for helping pronunciation, but also for exhausting other English skills, mainly vocabulary and listening. The description of these applications will be shown as follow and has limited on the free version reviews.

\section{Pronunciation Applications}

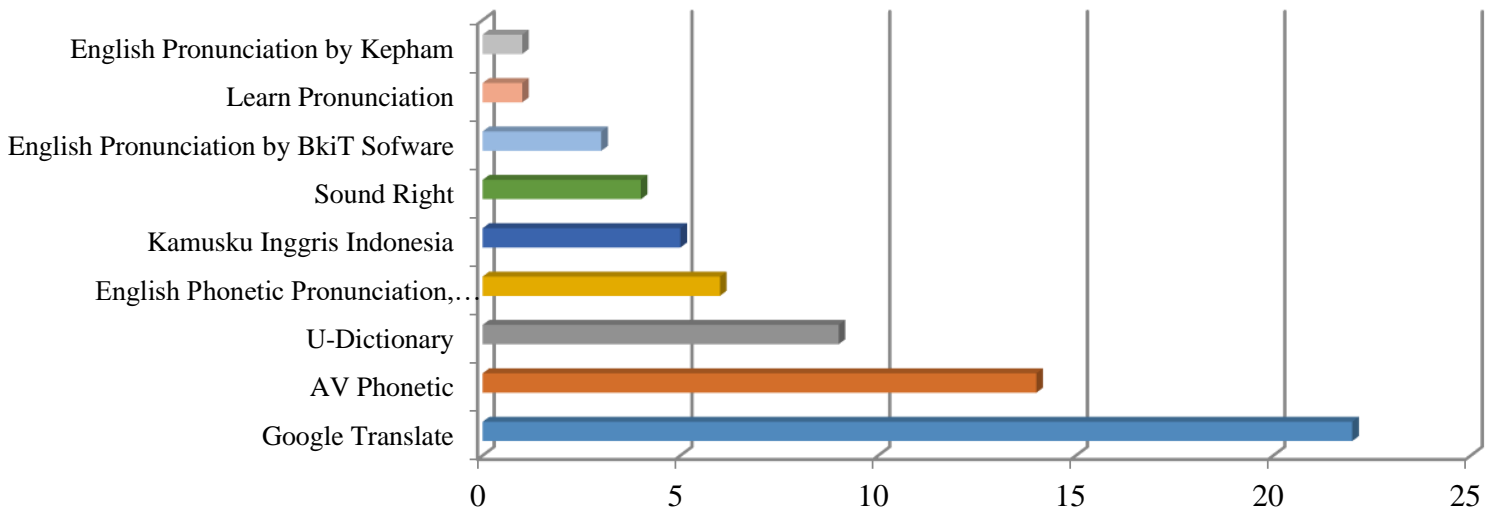

Figure 1. Kind of pronunciation and phonetics applications

AV Phonetic is an application that offers in a free version and can be used as an orientation for an interactive audio-visual of international phonetics alphabets (IPA). This application focuses on the segmental (consonants and vowels) and suprasegmental (tonal notation) practices. The segmental category consists of forty-eight consonant sounds and twenty-eight vowel sounds describing the characteristic of sound production. A cross-section animation of articulation producing followed by a gif picture, image, and embedded audio that shows the speech organs diagram, such as tongue and throat. On the left side of the cross-section animation, it displays the spectrogram to analyze the spectrum of the waveform in the voice signal at frequent periods stages. Concerning the suprasegmental category, it offers various tonal notations within different levels of tones and contours. The level of tones is developed by the system of tone letter of Chao's (1930), which uses a scale of 1-5. The tonal notation illustrated in the interactive music of the flute instrument. There are five types of flat tones: rising, falling, concave, convex, and contour. This application is also fully completed with a game, but it only immersive aspect forms without any guidance or opportunities for reproducing sound symbols to enhance students' pronunciation. The game asked to guess the right sound-symbol based on the model's pronunciation.

Regarding the exploration of the application features, this study found that $86 \%$ of students took beneficial of AV Phonetic to assist segmental learning. As student-2 said, she 
stated that this application was helpful to understand whether the organ speech was functioning to produce sound. She told in the second and fourth meeting of the course when the researcher described segmental and suprasegmental, and manner and place of articulation, they were a little bit hard to remember of what active organ to producing sound concerning the phonetics utterances, such as alveolar, palatal, fricative, approximant, and soon. Another point of view came from the next participant that coded as student-19. He postulated that this application was an interactive, clickable application that offered a free of charge and userfriendly; no need register an internet connection was available. $\mathrm{He}$ also added that this application alike virtual reality instead of he can be looked out the speech organ was working to produce a sound.

As an application that is available in the free version, English Phonetic Pronunciation, Listening Practice application offers a practical pronunciation for twenty-four consonant sounds, eleventh vocal sounds, and five diphthong sounds, which packaged in two forms, namely simulation video and simulated audio. Video simulation gives a watching position of the mouth, lips, tongue, and teeth following explanatory of a native speaker model. The application is embedded with an audio recorder to practice the sounds of a word - the audio recorder provided feedback about the pronunciation accuracy. In the free version, students offer two items option of learning, namely lesson and practice. In the lesson option, the given feedback is not specific, showing accurate or inaccurate (correct or wrong) compared with the pronunciation of the native speaker model. On the other hand, the option of practicing, the feedback displays with the statistical, which has drawn an accuracy graphic. In this option, students not only permit to practice pronunciation of words but also practice phrases and sentences with the amount of exercise pronunciation ranged between 39 and 58 pronunciation tests. However, it does not allow the whole segmental category to be available in the free version; only 24 of the 40 sound practices can be accessed. All features are available in the application that can be used online or requires a connection internet.

Although English Phonetic Pronunciation, Listening Practice application was a farreaching the students' need for pronunciation and phonetics learning, contrast, there was 33\% who found the value of this application. The researcher noted what student-25 said in the short interview moment that this application was substantial in bandwidth. She commented that this application was the first another pronunciation and phonetics exception of the two applications as the researcher referencing. In contrast with the previous statement, student-15 stated that she loved this application because it allowed audio-visual explanation. When the 
researcher offended the internet connection, she was not worried because her home had a noncable network; therefore, she could freely use it.

The third application is Sound Right that provides forty-four sound symbols consisting of twenty-four consonants, twelve vowels, and eight diphthongs. This application runs with audio as the main feature of the simulation of sound symbols and three examples of words representing each symbol. According to the limitation supporting feature, this application was not gain for pronunciation and phonetics learning. Even though $75 \%$ of students stated this application was simple to remember forty-four of the segmental sound, they were not specific about the benefit of using this application for their learning. As student- 11 said, this application was useful for distinguishing several phonemes in the dental fricative and postalveolar fricative by repeatedly clicking the phonemes.

Similar to Sound Right application, English Pronunciation by BkiT Software arranges for forty-four sound symbols consisting of twenty-four consonants, twelve vowels, and eight diphthongs. In view forward of the application, the categorization of phones displays in a choice-line, namely short vowels, long vowels, double vowels, voiceless consonants, voiced consonants, and other consonants. This application embeds audio and video to describe the position of speech organs when producing sound. Students may choose 20 to 60 examples of word pronunciation in different accents: British English and American English. This application also fulfills several pronunciations practicing features such as audio recorder, audio playback, and feedback. Students can be practiced their pronunciation of sixty words. The feedback in this application is marked with a star ( 1 up to 5) to remark the pronunciation accuracy. Not just dealing with pronunciation practice, this application delivers the game, a quiz that contains multiple-choice related to segmental particular in word, and the writing test to reinforce the word spelling based on the phonetics transcription. Each game as akin as pronunciation practice, consist of sixty test question. The developer compromises this application, both offline and online exposure. The primary differentiation between offline and online mode is placed on the supporting feature that is available. This application allows the audio recorder, audio playback, video, accent, and feedback in online usage. While, in the case that is not able to connect to the internet, students impartial to be accessed the second audio recorder in green color and audio playback.

This study compiled $67 \%$ positive feedback from three students who installed the English Pronunciation application by BkiT Software for their learning. They argued that this application makes it easier to find many words which included in an individual phoneme. As the comment from student-20, she got efficiency in searching a list of words that have the 
same sounding of the phoneme, but they have several letter combinations. She identified the phoneme /e/might consist of the letter and combination letter of e, a, and ed by looking at the list of example words. On the other hand, student-39 gave a negative prescriptive of this application. She told the researcher that she enthusiastic at the first of installing the application. At that time, she got public Wi-Fi to access all of the supporting features. Nevertheless, she got disappointed when there is no internet connection; she cannot measure her pronunciation due the feedback has unavailable.

Learn pronunciation offers forty-four sound symbols consisting of twenty-four consonants, twelve vowels, and eight diphthongs. This application embeds an audio recorder and feedback (marked with a star 1 up to 5) to measure pronunciation accuracy. There were available 3,400 words to practice pronunciation. Not only focus on practicing pronunciation, but this application also provides a dictionary and examples of the use of particular vocabulary in sentences a few sentences. In the free demo version, the external video link to YouTube cannot be accessed. This application has not distinguished the availability of supporting features for offline and online access. With the little user experience, this study argued what student-27 said the existent of ads was a little bit disturbed. However, she admired the user interface and eye-catching application preface.

English Pronunciation by Kepham is an application that supports segmental and suprasegmental learning. Using categorizing of segmental sounds like English Pronunciation by BkiT Software and Learn Pronunciation, this application offers various features, namely signals, examples, and comparing phonetics. Signals refer to words containing letters for each segmental sound with 15 to 59 words example. Each segmental sound has 1 to 7 variants of words contain letters. For example phoneme /u:/ have seven words contain a letter, namely oo (school, room, etc.), u (truth, music, etc.), ew (threw, chew, etc.), o (do, prove, etc.), ue (glue, true, etc. ), ou (group, soup, etc.), and ui (fruit, recruit, etc.). While, the phonemes $/ \mathrm{m} /, / \mathrm{n} /$, $/ \theta /, / \partial /$ are only consist of one containing letter. The example feature offers an example of phrases and sentences in each segment with the number of variations around 3 to 7 for phrases and 3 to 5 for sentences. Some phonemes such as $/ \mathrm{t} / \mathrm{l} / \mathrm{d} 3 /, / \mathrm{y} /, / \mathrm{h} /, / 1 /, / \mathrm{r} /, / \mathrm{w} /$, and $/ \mathrm{j} /$ do not accompanies example of phrases. The phonetics comparing show minimal pair with the number of variations around 2 to the 9 of word comparison. Not all of the segment has phonetics compared; diphthongs and several consonants that identified incomplete phrases examples are not having minimal pair. Another feature is word stress rules that are included syllables, word stress, and sentence stress. As reinforcement of the stress rules, this application inserts three types of games: writing the phonetics, guessing the number of 
syllables, and finding a stressed syllable. All the features that are described above can be used in an offline mode. Like other pronunciation applications, this application embeds an audio recorder for pronunciation practices and feedback (a star 1 to 3), internal video, and text translation. The last features are available to access with an internet connection. From a variety of features in the free version, several features such as signals, games, and pronunciation practice only to be accessible utmost until the sixth examples, while phonetics comparing can be admittance for two minimal pairs.

Categorizing in EDAP application, Google Translate, U-Dictionary, and Kamusku Inggris Indonesia offer a free version that can be used to practice pronunciation with an internet connection. Besides, Google Translate and U-Dictionary offer the other feature, i.e., text transcription. Among the three applications above, U-Dictionary is one application that offers other features such as accent, audio playback, and several videos to display certain words in sentences. To measure students' Pronunciation, U-Dictionary brings feedback that is marked in a star (1 to 5) and percentage for their fluency and sentence finishing. These studies found that those applications were beneficial for several English skills, pronunciation, vocabulary, and grammar. When focusing on pronunciation practice, this study highlighted that Kamusku Inggris Indonesia was the less application to do speech to text (20\%). It was postulated by student-30 who said she rarely used an audio recorder when searching a word. She has had a bad experience using an audio recorder due to mostly words that she said is not detected by the application. The student-30 statement was not different from student-22, who said that during the has been used Google Translate, no more trying to practice pronunciation. Sometimes, he used a conversation feature to arrange a sentence, but the result did not satisfy. His pronounce was not accurate to deliver what he is saying. Placing in the middle position of advantageous pronunciation application (68\%), Google Translate got a noteworthy suggestion to fulfill with feedback as the student-13 said in the interview. She thought that her pronunciation practice was incomplete if she did not have feedback on her accuracy and fluency. As a complete application, U-Dictionary showed $89 \%$ positive feedback from the student. However, this application needed to remove the ads as student-5 said.

Table 1. Application details

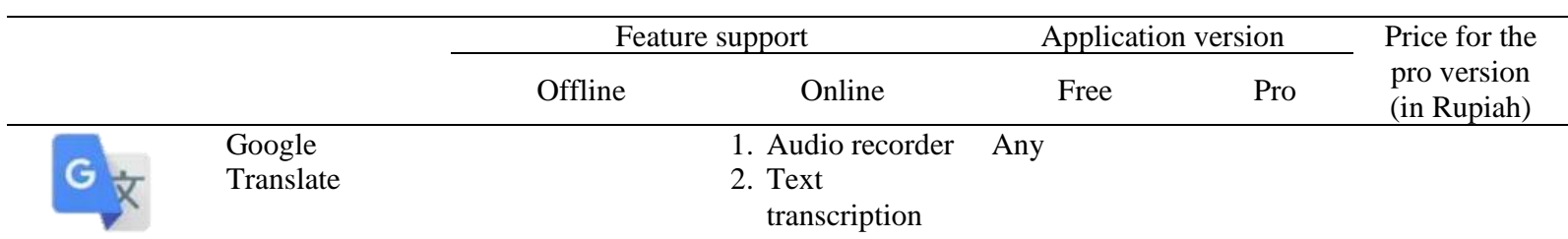




\begin{tabular}{|c|c|c|c|c|c|c|}
\hline & & \multicolumn{2}{|c|}{ Feature support } & \multicolumn{2}{|c|}{ Application version } & \multirow{2}{*}{$\begin{array}{l}\text { Price for the } \\
\text { pro version } \\
\text { (in Rupiah) }\end{array}$} \\
\hline & & Offline & Online & Free & Pro & \\
\hline $\begin{array}{l}\text { interactive } \\
\text { phonet ics } \\
\text { /fa'netiks/ }\end{array}$ & AV Phonet ic & $\begin{array}{l}\text { 1. Phonemics } \\
\text { chart (48 } \\
\text { consonants and } \\
28 \text { vowels) and } \\
\text { description } \\
\text { 2. A cross-section } \\
\text { of animation } \\
\text { with } \\
\text { spectrogram } \\
\text { (except vowel) } \\
\text { 3. Tonal notation } \\
\text { (flat, rising, } \\
\text { falling, } \\
\text { concave, and } \\
\text { convex) and } \\
\text { contour } \\
\text { 4. Game }\end{array}$ & & Any & & \\
\hline & U-Dictionary & & $\begin{array}{l}\text { 1. Audio } \\
\text { recorder and } \\
\text { audio } \\
\text { playback } \\
\text { 2. Video } \\
\text { 3. Text } \\
\text { transcription } \\
\text { 4. Accent } \\
\text { 5. Feedback }\end{array}$ & Any with ads & No ads & $\begin{array}{l}30,000 \\
\text { /month }\end{array}$ \\
\hline 22 & $\begin{array}{l}\text { English } \\
\text { Phonetic } \\
\text { Pronunciation, } \\
\text { Listening } \\
\text { Practice }\end{array}$ & $\begin{array}{l}\text { Phonemics chart } \\
\text { ( } 24 \text { consonants, } \\
11 \text { vowels, and } \\
\text { five diphthongs) } \\
\text { and description }\end{array}$ & $\begin{array}{l}\text { 1. Phonemics } \\
\text { chart ( } 24 \\
\text { consonants, } 11 \\
\text { vowels, and } \\
\text { five } \\
\text { diphthongs) } \\
\text { and } \\
\text { description } \\
\text { 2. Audio } \\
\text { recorder } \\
\text { 3. Video } \\
\text { 4. Feedback } \\
\text { 5. Practicing } \\
\text { word, phrase, } \\
\text { and sentence }\end{array}$ & $\begin{array}{l}\text { 1. A quick } \\
\text { lesson and } \\
\text { full lesson } \\
\text { 2. Practicing } \\
\text { word, } \\
\text { phrase, and } \\
\text { sentence } \\
\text { from } 24 \\
\text { sound } \\
\text { symbols }\end{array}$ & $\begin{array}{l}\text { 1. All } \\
\text { featur } \\
\text { es } \\
\text { 2. No } \\
\text { ads }\end{array}$ & $\begin{array}{l}24,455- \\
259,000 / \text { item }\end{array}$ \\
\hline$\frac{1}{4 s}$ & $\begin{array}{l}\text { Kamusku } \\
\text { Inggris } \\
\text { Indonesia }\end{array}$ & & Audio recorder & & & \\
\hline 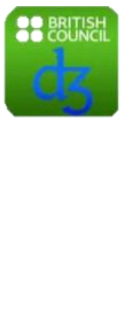 & Sound Right & $\begin{array}{l}\text { 1. Phonemics } \\
\text { chart ( } 24 \\
\text { consonants, } 12 \\
\text { vowels, and } \\
\text { eight } \\
\text { diphthongs) } \\
\text { 2. Practice three } \\
\text { words of each } \\
\text { phoneme }\end{array}$ & & Any & & \\
\hline $\begin{array}{l}\text { English } \\
\text { Pronunciation } \\
\text { laul lua/ }\end{array}$ & $\begin{array}{l}\text { English } \\
\text { Pronunciation } \\
\text { by BkiT } \\
\text { Sofware }\end{array}$ & $\begin{array}{l}\text { 1. Phonemics } \\
\text { chart ( } 24 \\
\text { consonants, } 12 \\
\text { vowels, and } 8 \\
\text { diphthongs) } \\
\text { 2. Audio recorder } \\
\text { (second audio } \\
\text { recorder) and } \\
\text { audio playback } \\
\text { 3. Game }\end{array}$ & $\begin{array}{l}\text { 1. Phonemics } \\
\text { chart ( } 24 \\
\text { consonants, } 12 \\
\text { vowels, and } 8 \\
\text { diphthongs) } \\
\text { 2. Audio recorder } \\
\text { and audio } \\
\text { playback } \\
\text { 3. Video } \\
\text { 4. Accent } \\
\text { 5. Feedback }\end{array}$ & Any & & \\
\hline
\end{tabular}




\begin{tabular}{llcccc}
\hline & \multicolumn{2}{c}{ Feature support } & \multicolumn{2}{c}{ Application version } & $\begin{array}{c}\text { Price for the } \\
\text { pro version } \\
\text { (in Rupiah) }\end{array}$ \\
\cline { 2 - 5 }
\end{tabular}

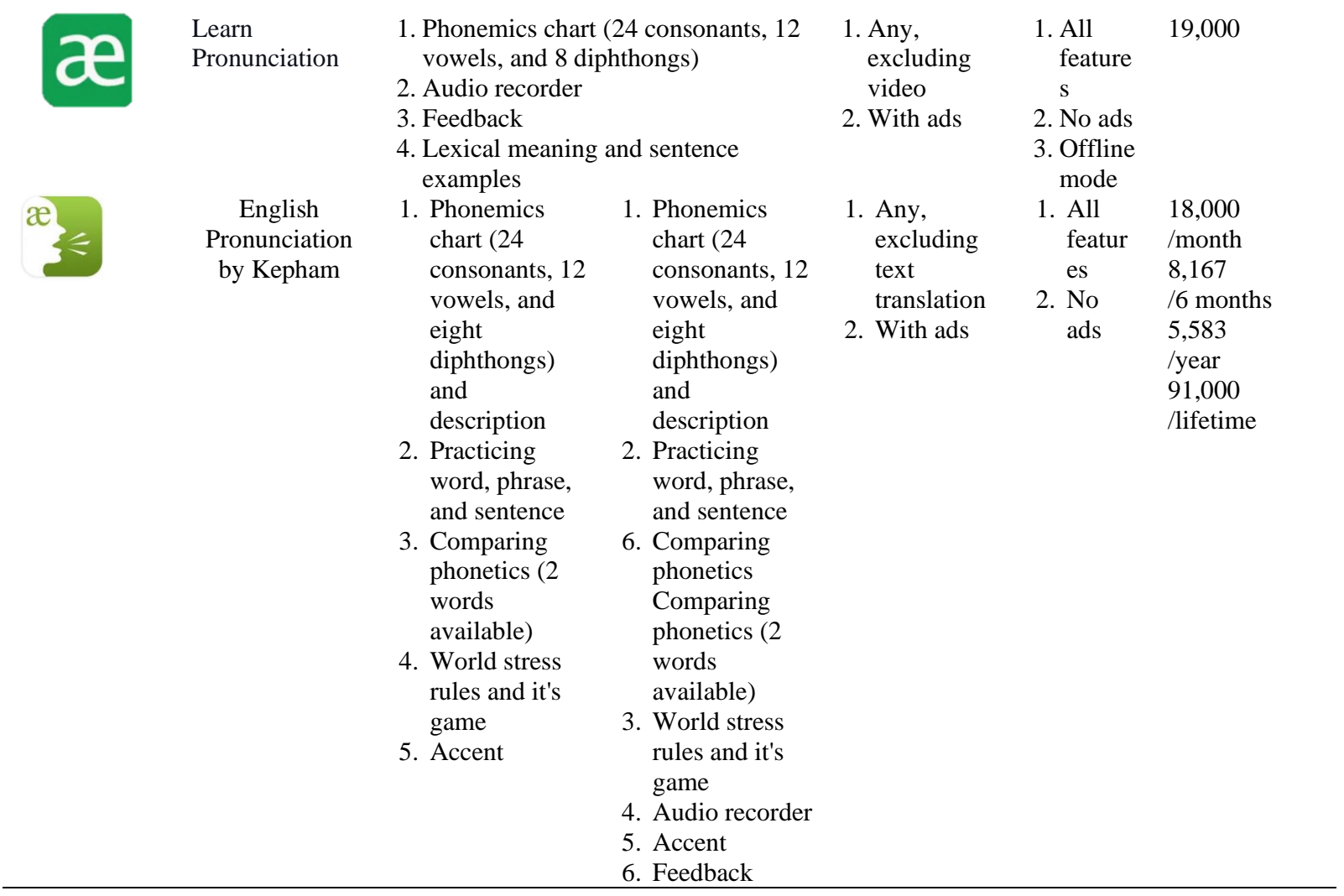

\section{DISCUSSION}

Not all of the applications had specific criteria to fulfill the students' need for their pronunciation and phonetics practices. Nevertheless, they should have been analyzed as well as being amongst phonetic features. As mentioned earlier in the literature review, pronunciation and phonetics focused on several aspects of the content and the design.

\subsection{Content approaches}

Content approaches, an application of pronunciation and phonetic was served at least ten features. Modifying Walesiak (2017) features, this present study also used as similar as features, namely (1) voice production warm-ups; (2) acknowledging IPA; (3) articulation of specific sounds; (4) listening and distinguishing sound; (5) text transcription; (6) pronouncing words and phrases; (7) practice in word stress; (8) practices in linked speech; (9) practice in rhythm and intonation; and (10) learning about the accent. As we can see in Table 2, no application fulfilled all of the content approaches' features. Focusing on the EPSP application, there were two applications i.e., English Phonetic Pronunciation, Listening Practice, and English Pronunciation by BkiT Software have already fulfilled seven of ten 
features. The rest was about three to six features that can be contented in the application. The Sound Right was the highest uncompleted application to assist students' practice rather than the rest application. However, English Pronunciation by Kepham as the less installing application brought more features than eight features.

Most applications were not completed with acknowledging IPA; there was only one application does so. Without this feature, students were absurd to pronounce because they did not perceive consonants and vowels chart. Although other studies have been reported that IPA was useful to encourage the effectiveness of teaching pronunciation (Baker \& Burri, 2016; Burri, 2016), the developer of mobile application seems not to take the potential of the present it as a pre-knowledge for learning pronunciation.

No less important was how the application could help students practice linked speech, rhythm, and intonation. Concerning the result of this study, not all EPSP applications considered these features; several of them just provided two of four features. Previous studies found that these features were the common barriers in suprasegmental (Burri, 2016; Buss, 2016; Couper, 2017; Foote et al., 2016). Although the presence of them on the mobile application was not affected on intelligibility (Darcy, 2018) but it should be aware. It was concerning what Wichmann (2015) said that it was hard on giving feedback in line with the limitation of time teaching and teachers' competency (Jing, 2017; Xiao \& Luo, 2015; Zielinski, 2015). This finding is linked with Kaiser's (2018) study, which stresses on suprasegmental features. A worthy finding was the EDAP application, such as U-Dictionary, worked with these features.

Both EPSP applications and EDAP application did not pay attention to different varieties of English in term of ELF that could improve intelligibility in teaching and learning pronunciation (Buss, 2016; Lim, 2016; O'Neal, 2015; Sun, 2017; Véliz-Campos, 2018; Walker \& Zoghbor, 2015; Zoghbor, 2018). Most applications were available in the standard English-speaking accent; American English and British English. Therefore, pronunciation applications were revealed biases toward the non-native English' paradigm of English varieties that were viewed as inferior varieties in comparison to native pronunciation.

This study found one application regarding learning pronunciation strategies, namely English pronunciation, by Kepham, which fully completed to cognitive strategies, i.e., pronunciation rule and minimal pair (Mirza, 2015; Szyszka, 2015). Pronunciation rule identified on suprasegmental features, i.e., syllable structure and stress. Stress production was one of the most common challenges for Pronunciation (Burri, 2016; Buss, 2016; Couper, 2017; Foote et al., 2016; Kaiser, 2018; Walesiak, 2017). According to a previous study by 
Buss (2016), minimal pair is one of the segmental features that was faced difficult. Therefore, this present study has been given a solution to the application choice for word stress and minimal pair.

AV Phonetic

U-Dictionary

English Phonetic Pronunciation,

Kamusku Inggris Indonesia

\section{Sound Right}

\subsection{Design approaches}

A design approach refers to MAPT features that were needed by the students. In this study, the researcher excluded some features of MAPT proposed by Kaiser (2018). Therefore, this study focused on features in a real-time practice and evaluation, such as: (1) audio recorder (2) audio playback; (3) video (or external video); (4) feedback; (5) video 
camera recorder; and (6) accelerometer. Like the display in Table 3, no application fulfilled all of the features in the content approaches. All of the applications were no complemented with video camera recorders to give the students visual feedback on how they produced the sound. Besides, most of the applications were no embedded with the features of audio playback.

Focusing on each category application, both EPSP application and EDAP application, there were two applications, i.e., English Pronunciation by Kepham and U-Dictionary, which have already fulfilled five of six features. Even, there was surprising several EPSP applications, i.e., AV Phonetic and Sound Right have no completed with all of the features of MAPT. It assumed the two applications did not function for pronunciation practices; indeed, it mainly focused on phonetics' preliminary knowledge. Therefore, both of them did not fulfill the requirement as previous studies Kaiser (2018) and Walesiak (2017) focusing on pertinent to MAPT. Comparing with the other application in the same category of EPSP application, English Phonetic Pronunciation, Listening Practice application was more useable to practice pronunciation and learned segmental aspects and almost quite entirely with the MAPT criterion (Kaiser, 2018).

Tabel 3. Design approaches to pronunciation and phonetics application

\begin{tabular}{|c|c|c|c|c|c|c|c|}
\hline & & 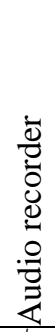 & 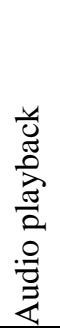 & 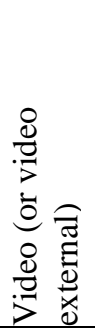 & 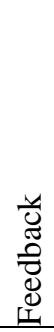 & 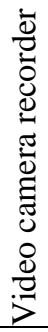 & 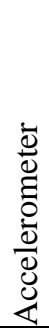 \\
\hline & Google Translate & $\sqrt{ }$ & & & & & \\
\hline $\begin{array}{l}\text { interactive } \\
\text { Shonet ics }\end{array}$ & AV Phonetic & & & & & & \\
\hline & U-Dictionary & $\sqrt{ }$ & $\sqrt{ }$ & $\sqrt{ }$ & $\sqrt{ }$ & & $\sqrt{ }$ \\
\hline & English Phonetic Pronunciation, Listening Practice & $\sqrt{ }$ & & $\sqrt{ }$ & $\sqrt{ }$ & & $\sqrt{ }$ \\
\hline & Kamusku Inggris Indonesia & $\sqrt{ }$ & & & & & \\
\hline 88 8ROTH & Sound Right & & & & & & \\
\hline $\begin{array}{l}\text { English } \\
\text { Pronunciation } \\
\text { laul lual }\end{array}$ & English Pronunciation by BkiT Sofware & $\sqrt{ }$ & & $\sqrt{ }$ & $\sqrt{ }$ & & $\sqrt{ }$ \\
\hline
\end{tabular}




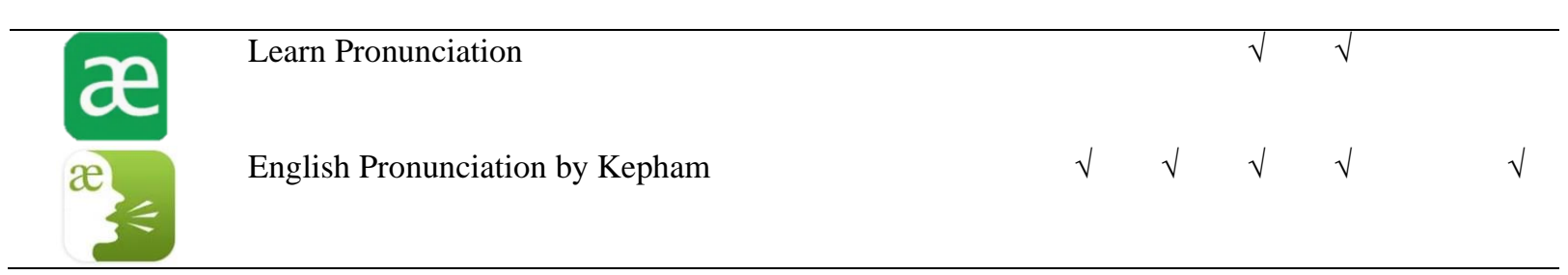

\section{CONCLUSION}

The study is aimed to present the usefulness of mobile applications to push the practical side of MAPT, Pronunciation, and phonetic technology at hand. However, this study does not support absolute dependence on mobile applications for pronunciation. The fact that technology provides many realistic incentives is undoubtedly beneficial for learning strategies. Knowing the supporting features in a mobile application, then selecting the recommended application makes the students' need for more efficient pronunciation practice.

Based on the researcher's personal preferences, some mobile applications suggested in this study for pronunciation and phonetics learning are AV Phonetic, English Phonetic Pronunciation, Listening Practice, English Pronunciation developed by Kepham, and UDictionary. The factor in determining these recommendations concerns the term of Mobile Assisted Pronunciation Training (MAPT) which is classified on the content approaches and design approaches that are closer to students' needs in pronunciation practice. Furthermore, this study requires a longitudinal study to measure mobile applications' effectiveness to improve learning pronunciation and phonetics.

\section{REFERENCES}

Abduh, M. Y. M. (2019). The effect of implementing MALL applications on learning pronunciation of English by EFL learners at Najran University. International Journal of Linguistics, 11(6), 29. https://doi.org/10.5296/ijl.v11i6.15814

Alameen, G., \& Levis, J. M. (2015). Connected speech. In M. Reed \& J. M. Levis (Eds.), The Handbook of English Pronunciation (pp. 157-174). Wiley. https://doi.org/10.1002/9781118346952.ch9

Arashnia, M., \& Shahrokhi, M. (2016). Mobile assisted language learning: English pronunciation among Iranian pre-intermediate EFL learners. Journal of Applied Linguistics and Language Research, 3(4), 149-162. http://jallr.com/ jallrir/index.php/JALLR/article/view/334

Baker, A., \& Burri, M. (2016). Feedback on second language pronunciation: A case study of EAP teachers' beliefs and practices. Australian Journal of Teacher Education, 41(6), 1-19. https://doi.org/10.14221/ajte.2016v41n6.1

Burri, M. S. (2016). "It's been a real eye opener": learning to teach English pronunciation from a teacher cognition perspective [University of Wollongong]. https://ro.uow.edu.au/theses/4764

Buss, L. (2016). Beliefs and practices of Brazilian EFL teachers regarding pronunciation. Language Teaching Research, 20(5), 619-637. https://doi.org/10.1177/1362168815574145 
Byrne, J., \& Diem, R. (2014). Profiling mobile English language learners. The Jalt Call Journal, 10(1), 3-19.

Couper, G. (2017). Teacher cognition of pronunciation teaching: Teachers' concerns and issues. TESOL Quarterly, 51(4), 820-843. https://doi.org/10.1002/tesq.354

Couper, G. (2019). Teachers' cognitions of corrective feedback on pronunciation: Their beliefs, perceptions and practices. System, 84, 41-52. https://doi.org/10.1016/j.system.2019.04.003

Crowther, D., Trofimovich, P., Saito, K., \& Isaacs, T. (2015). Second language comprehensibility revisited: Investigating the effects of learner background. TESOL Quarterly, 49(4), 814-837. https://doi.org/10.1002/tesq.203

Cutler, A. (2015). Lexical stress in English pronunciation. In M. Reed \& J. M. Levis (Eds.), The Handbook of English Pronunciation (1st ed., pp. 106-124). Wiley. https://doi.org/10.1002/9781118346952.ch6

Darcy, I. (2018). Powerful and effective pronunciation instruction: How can we achieve it? CATESOL Journal, 30(1), 13-45.

Deterding, D. (2015). Segmentals. In M. Reed \& J. M. Levis (Eds.), The Handbook of English Pronunciation (1st ed., pp. 67-84). Wiley. https://doi.org/10.1002/9781118346952.ch4

Foote, J. A., Trofimovich, P., Collins, L., \& Urzúa, F. S. (2016). Pronunciation teaching practices in communicative second language classes. The Language Learning Journal, 44(2), 181-196. https://doi.org/10.1080/09571736.2013.784345

Fouz-González, J. (2015). Trends and directions in computer-assisted pronunciation training. In Investigating English Pronunciation (pp. 314-342). Palgrave Macmillan UK. https://doi.org/10.1057/9781137509437_14

Ghounane, N. (2019). The attitudes of second year EFL students at Dr Moulay Tahar University towards learning English pronunciation through mobile assisted language. Arab World English Journal, 5, 110-123. https://doi.org/10.24093/awej/call5.9

Gooch, R., Saito, K., \& Lyster, R. (2016). Effects of recasts and prompts on L2 pronunciation development: Teaching English / / / to Korean adult EFL learners. System, 60, 117-127. https://doi.org/10.1016/j.system.2016.06.007

Haggag, H. M. (2018). Teaching phonetics using a mobile-based application in an EFL context. European Scientific Journal, ESJ, 14(14), 189. https://doi.org/10.19044/esj.2018.v14n14p189

Hincks, R. (2015). Technology and learning pronunciation. In M. Reed \& J. M. Levis (Eds.), The Handbook of English Pronunciation (pp. 505-519). Wiley. https://doi.org/10.1002/9781118346952.ch28

Jing, X. (2017). Application of mobile learning system in phonetics teaching. Proceedings of the 8th International Conference on E-Education, E-Business, E-Management and ELearning - IC4E '17, 19-23. https://doi.org/10.1145/3026480.3026486

Kaiser, D. (2018). Mobile-assisted pronunciation training: The iPhone pronunciation app project. IATEFL Pronunciation Special Interest Group Journal, 58, 38-52.

Kemp, S. (2020). Digital 2020: Indonesia. Datareportal. https://datareportal.com/reports/digital-2020-indonesia

Levis, J. M., \& Wichmann, A. (2015). English intonation - form and meaning. In M. Reed \& J. M. Levis (Eds.), The Handbook of English Pronunciation (pp. 139-155). Wiley. https://doi.org/10.1002/9781118346952.ch8 
Lim, S. (2016). Learning to teach intelligible pronunciation for ASEAN English as a Lingua Franca: A sociocultural investigation of Cambodian pre-service teacher cognition and practice. RELC Journal, 47(3), 313-329. https://doi.org/10.1177/0033688216631176

Low, E. (2015). The rhythmic patterning of English(es). In M. Reed \& J. M. Levis (Eds.), The Handbook of English Pronunciation (pp. 125-138). Wiley. https://doi.org/10.1002/9781118346952.ch7

Ma'u, J. A. R. Z., Fajaruddin, S., Lamahala, C. B. M., Fuadi, C., Perdana, S., \& Aryanto, A. (2019). Submissiveness and resistance: Different paradigm between Indonesian language and English. LingTera, 6(1). https://doi.org/10.21831/LT.V6I1.23966

Mahdi, H. S., \& Al Khateeb, A. A. (2019). The effectiveness of computer-assisted pronunciation training: A meta-analysis. Review of Education, 7(3), 733-753. https://doi.org/10.1002/rev3.3165

Martins, C. G. D. F. M., Borges, V. M. C., \& Levis, J. M. (2016). The design of an instrument to evaluate sotware for EFL/ESL pronunciation teaching. Ilha Do Desterro A Journal of English Language, Literatures in English and Cultural Studies, 69(1), 141. https://doi.org/10.5007/2175-8026.2016v69n1p141

Mirza, H. S. (2015). ESL and EFL learners improve differently in pronunciation: The case of Lebanon. Procedia - Social and Behavioral Sciences, 199, 486-495. https://doi.org/10.1016/j.sbspro.2015.07.536

Mompean, J. A., \& Fouz-González, J. (2016). Twitter-based EFL pronunciation instruction. Language Learning and Technology, 20(1), 166-190. https://doi.org/10125/44451

Moreno, A. I., \& Vermeulen, A. (2015). Using VISP (videos for speaking), a mobile app based on audio description, to promote English language learning among Spanish students: A case study. Procedia - Social and Behavioral Sciences, 178, 132-138. https://doi.org/10.1016/j.sbspro.2015.03.169

Munro, M. J., \& Derwing, T. M. (2015). Intelligibility in research and practice. In M. Reed \& J. M. Levis (Eds.), The Handbook of English Pronunciation (pp. 375-396). Wiley. https://doi.org/10.1002/9781118346952.ch21

Murphy, J. M., \& Baker, A. A. (2015). History of ESL pronunciation teaching. In M. Reed \& J. M. Levis (Eds.), The Handbook of English Pronunciation (pp. 36-65). Wiley. https://doi.org/10.1002/9781118346952.ch3

O’Neal, G. (2015). Segmental repair and interactional intelligibility: The relationship between consonant deletion, consonant insertion, and pronunciation intelligibility in English as a Lingua Franca in Japan. Journal of Pragmatics, 85, 122-134. https://doi.org/10.1016/j.pragma.2015.06.013

Reed, M., \& Levis, J. M. (2015). The handbook of English pronunciation. In Marnie Reed \& J. M. Levis (Eds.), The Handbook of English Pronunciation (1st ed.). Wiley. https://doi.org/10.1002/9781118346952

Saito, Y., \& Saito, K. (2017). Differential effects of instruction on the development of second language comprehensibility, word stress, rhythm, and intonation: The case of inexperienced Japanese EFL learners. Language Teaching Research, 21(5), 589-608. https://doi.org/10.1177/1362168816643111

Statista. (2019). Market share of mobile operating systems in Indonesia from January 2012 to December 2019*. https://gs.statcounter.com/os-market-share/mobile/indonesia

Statista. (2020). Number of available apps at Google Play from 2nd quarter 2015 to 2 nd quarter 2020. Statista. https://www.statista.com/statistics/289418/number-of-availableapps-in-the-google-play-store-quarter/ 
Sun, Y. (2017). The design and application of English pronunciation training software based on Android intelligent mobile phone platform. Revista de La Facultad de Ingeniería, 32(5), 756-765.

Szyszka, M. (2015). Good English pronunciation users and their pronunciation learning strategies. Research in Language, 13(1), 93-106. https://doi.org/10.1515/rela-20150017

Thomson, R. I., \& Derwing, T. M. (2015). The effectiveness of L2 pronunciation instruction: A narrative review. Applied Linguistics, 36(3), 326-344. https://doi.org/10.1093/applin/amu076

Véliz-Campos, M. (2018). Pronunciation learning strategies, aptitude, and their relationship with pronunciation performance in pre-service English language teachers in Chile. Iranian Journal of Language Teaching Research, 6(2), 57-76. http://ijltr.urmia.ac.ir/article_120560.html

Walesiak, B. (2017). Mobile pron. apps - a personal investigation. Speak Out! Journal of the IATEFL Pronunciation Special Interest Group, 57, 16-28.

Walker, R., \& Zoghbor, W. (2015). The pronunciation of English as a Lingua Franca. In M. Reed \& J. M. Levis (Eds.), The Handbook of English Pronunciation (pp. 433-453). Wiley. https://doi.org/10.1002/9781118346952.ch24

Wichmann, A. (2015). Functions of intonation in discourse. In M. Reed \& J. M. Levis (Eds.), The Handbook of English Pronunciation (pp. 175-189). Wiley. https://doi.org/10.1002/9781118346952.ch10

Xiao, J., \& Luo, Y. (2015). Application of mobile learning system in phonetics teaching. Proceedings of the 2015 International Conference on Social Science, Education Management and Sports Education, 4. https://doi.org/10.2991/ssemse-15.2015.312

Zielinski, B. (2015). The segmental/suprasegmental debate. In M. Reed \& J. M. Levis (Eds.), The Handbook of English Pronunciation (pp. 397-412). Wiley. https://doi.org/10.1002/9781118346952.ch22

Zoghbor, W. S. (2018). Teaching English pronunciation to multi-dialect first language learners: The revival of the Lingua Franca Core (LFC). System, 78, 1-14. https://doi.org/10.1016/j.system.2018.06.008 